\title{
Use of coping strategies in MND/ALS: association with demographic and disease-related
}

\section{characteristics}

Schlüter $\mathrm{DK}^{1}$, Holland $\mathrm{D}^{2}$, Mills $\mathrm{RJ}^{3}$, Young $\mathrm{CA}^{2,3}$ on behalf of the TONiC study group

$\sim$ TONiC study group:

Al-Chalabi $A^{4}$, Burke $G^{5}$, Dick $D^{6}{ }^{6}$, Ealing $\mathrm{J}^{7}$, McDermott $\mathrm{CJ}^{8}$, Majeed $\mathrm{T}^{9}$, Pinto $\mathrm{A}^{10}$, Talbot $\mathrm{K}^{11}$, Williams $\mathrm{T}^{12}$

${ }^{1}$ Lancaster University, UK

${ }^{2}$ University of Liverpool, UK

${ }^{3}$ Walton Centre NHS Trust, Liverpool, UK

${ }^{4}$ King's College London, UK

${ }^{5}$ Wessex Neurological Centre, UK

${ }^{6}$ Norfolk \& Norwich University Hospital, UK

${ }^{7}$ Salford Royal Foundation Trust, Manchester, UK

${ }^{8}$ Sheffield Institute for Translational Neuroscience, University of Sheffield, UK

${ }^{9}$ Lancashire Teaching Hospitals, Preston, UK

${ }^{10}$ Wessex Neurological Centre, UK

${ }^{11}$ University of Oxford, UK

${ }^{12}$ Royal Victoria Infirmary, Newcastle upon Tyne, UK

Corresponding author: Schlüter DK, Centre for Health Informatics, Computing and Statistics, Lancaster Medical School, Faculty of Health and Medicine, Lancaster University, Lancaster LA1 4YW, UK; e-mail: d.schlueter@lancaster.ac.uk

Word Count: 2740 
Running title:

Use of coping strategies in MND/ALS 


\begin{abstract}
Objective

Understanding the use of coping strategies and which factors are predictors of strategy utilisation might help clinical staff anticipate which coping strategies individuals are more likely to utilise. In this study we assess coping strategy use in the Motor Neurone Disease (MND, also known as Amyotrophic lateral sclerosis (ALS)) population, and examine associations of demographic and disease variables with individual coping strategies.

Participants and Methods

233 participants with MND/ALS were recruited into the ongoing Trajectories of Outcomes in Neurological Conditions (TONiC) study from MND clinics across the United Kingdom. Participants completed a questionnaire pack collecting data on demographics and a range of patient reported measures including the Coping Orientations to Problems Experienced scale. Associations between demographic and clinical characteristics and coping strategies were examined by simple and multiple ordinal logistic regression.

Results
\end{abstract}

The most commonly used strategy was Acceptance, followed by Active Coping, Planning and Positive Re-interpretation and Growth. The least used strategies were Substance Use, Turning to Religion and Denial. Ten out of the fifteen strategies showed statistically significant associations with demographic and clinical characteristics. Most markedly, females were found to utilise Restraint, Seeking Instrumental Social Support, Seeking Emotional Social Support, Focus on and Venting of Emotions, Behavioural Disengagement, and Mental Disengagement more than males.

Conclusion

Clinical staff should be aware of several disease and demographic characteristics that are associated with use of potentially maladaptive coping strategies or the underutilisation of coping strategies that may lead to better psychosocial adjustment.

Keywords: Amyotrophic Lateral Sclerosis, coping, Motor Neurone Disease, psychological adjustment, quality of life, TONiC 


\section{Introduction}

Motor Neurone Disease (MND, also known as Amyotrophic lateral sclerosis (ALS)) describes a group of diseases characterised by progressive degeneration of the motor neurones controlling voluntary muscles. This leads to widespread muscle weakness and wasting, affecting voluntary movement, speech, swallowing and breathing. Most people with MND die of respiratory failure within 3 to 5 years of symptom onset ${ }^{1,2}$. Currently there is no cure available and thus the main focus of care is on treating symptoms and improving quality of life. Previous studies have found that quality of life in MND is substantially affected by psychological factors and support from family and friends ${ }^{3-7}$. The constantly changing stresses of a progressively disabling, incurable and terminal condition like MND place considerable demands on patients' coping abilities.

Coping involves 'cognitive and behavioural efforts to manage specific external and/or internal demands that are appraised as taxing or exceeding the resources of the person ${ }^{8}$. There are two main groups of coping strategies, those that alter the situation that is causing distress (problemfocussed strategies) and those that reduce or manage the emotional response to the stressor (emotion-focussed strategies $)^{8}$. These two types of coping are complementary and are generally used together ${ }^{8}$, including in MND ${ }^{9,10}$. Both cross-sectional and longitudinal studies have found that coping capacity and the strategies used affect depressive symptoms and quality of life $5,6,9,11,12$.

The role of coping strategies in adjustment to MND has been the focus of a number of small studies $6,9,12$. The use of support and positive action have been found to correlate with lower levels of depression and anxiety, whereas avoidance and venting were positively correlated with increased levels of anxiety ${ }^{12}$. Similarly, patients who use positive action, positive thinking and independence were found to have fewer symptoms of depression ${ }^{9}$. The use of a group of coping strategies 
consisting of active coping, acceptance, planning and positive reframing has even been suggested to increase survival ${ }^{13}$.

Despite the evidence for the positive or negative impact of individual coping strategies, little is known about association between demographic and disease characteristics and the strategies patients turn to. One study by Montel and colleagues with 49 MND patients showed that age affected the use of emotional support, venting, positive reframing, planning, and humour, and that acceptance, positive reframing and humour were used more with increasing disease duration; onset type and functional status also showed some associations with strategy utilisation ${ }^{14}$. Other studies have not found any correlations of strategy use with demographic characteristics or have found changes in these over time ${ }^{10,12}$. The conflicting evidence may be due to the small sample sizes or the different instruments used in these studies. In order to increase the understanding of overall coping strategy use in MND patients and which factors affect the probability of an individual turning to a certain strategy, we address these questions using a very large population sample in the UK who completed the generic and broad 'Coping Orientations to Problems Experienced' (COPE60) questionnaire ${ }^{15}$.

\section{Methods}

\section{Data Collection}

Participants with MND were recruited into the ongoing Trajectories of Outcomes in Neurological Conditions (TONiC) study from specialist clinics across the United Kingdom. Following informed consent, participants completed a questionnaire pack, which could be done with the assistance of a caregiver acting as scribe if the patient could not write. Demographic and disease-specific data, as well as a range of patient reported measures, were collected in the pack. Demographic data included age, sex and marital status, where 'single', 'widowed' and 'divorced' were combined to 'not married'. Disease specific data included time since diagnosis ('disease duration'), onset type and 
functional ability in the limb, bulbar and respiratory domains captured by the ALS Functional Rating Scale Revised (ALSFRS-R) ${ }^{16}$. Confirmation of the clinical diagnosis, onset type and disease duration were additionally collected from a health care professional familiar with the patient's case. Ethical approval was granted from the relevant local research committees (reference 11/NW/0743).

\section{Coping}

Amongst the patient reported measures was the Coping Orientations to Problems Experienced $(\text { COPE60) })^{15}$ inventory, which was used in this study to assess 'dispositional coping', i.e. the extent to which the respondents usually use certain coping strategies. The inventory consists of 15 scales with 4 items each and includes problem focused coping strategies (active coping, planning, suppression of competing activities, restraint, seeking of instrumental social support), emotion focused coping strategies (seeking of emotional social support, positive reinterpretation and growth, acceptance, denial, turning to religion) and other coping strategies (focus on and venting of emotions, behavioural disengagement, emotional disengagement, humour, substance use). Table S1 in the Supplementary Material defines each of the 15 strategies.

Participants report their responses to each item on a 4-point Likert scale ( $1=$ I usually don't do this at all , 2 = I usually do this a little bit, $3=\mid$ usually do this a medium amount , $4=\mid$ usually do this a lot). The responses to the four items of any one scale are summated such that the use of each coping strategy is scored 0-12. For statistical analysis we collapsed these scores into 5 groups ('Not at all', 'A little', 'More than a little', 'A moderate amount', 'A lot') in order to ensure that groups are more reasonably populated (see Figure 1).

\section{Data Analysis}

Overall coping strategy use was assessed using the following summary measures: mode, median, $25 \%$ and $75 \%$ percentiles, minimum and maximum value. 
Rasch analysis ${ }^{17}$ was applied to the ordinal response data of the ALSFRS-R in order to arrive at interval level scales for the three domains: bulbar, limb and respiratory.

Ordinal logistic regression with cumulative logits was used to assess the associations of coping strategy use with demographic and disease specific characteristics. Proportional odds were assumed where this agreed with the available data. The proportional odds assumption was tested using a likelihood ratio test with a cut-off for significance at $p<0.01$ and, where the test was significant, the parameter estimates for the different levels were investigated to ensure that the proportional odds assumption was only rejected if there were clear differences in the effect of the covariate on strategy usage at the different levels and a clear trend was recognisable. This was done to ensure that the assumption of proportional odds was only rejected if there was strong evidence against it.

Univariable ordinal logistic regression was carried out initially. For coping strategies where one or more covariates were statistically significant at the $5 \%$ level, a multiple ordinal logistic regression model was developed using forward selection. In all cases, significance was assessed using a likelihood ratio test.

The statistical analysis was conducted using R version 3.3.1 and the vglm function of the VGAM package ${ }^{18}$ with the 'cumulative' and 'reverse=TRUE' VGAM family function options. Only complete cases were included in the analysis.

\section{Results}

267 individuals completed the pilot phase pack, which included the COPE60, of which 233 participants had complete coping and covariate data. Missing data was primarily an issue in the disease specific information (see Table 1); coping data was incomplete in 5 individuals. Table 1 shows the demographics and disease characteristics of the study population. 
While every strategy was used to some extent, frequency of use varied widely. The most commonly used strategy was Acceptance, with $79 \%$ of the individuals endorsing usage with a 6 or more on a scale from 0 to 12 , including $16 \%$ of the study population who endorsed it with the maximum score of 12. This was followed by Active Coping, Planning and Positive Re-interpretation and growth. The least used strategies were Substance Use, for which $82 \%$ reported use as 0 , Turning to religion and Denial. Table 2 show summaries of the overall usage of the 15 different coping strategies.

Associations with demographic and disease specific characteristics

Results from the univariable and multivariable regression analyses are given as odds ratios with $95 \%$ profile likelihood confidence intervals (Tables 3 and 4). Likelihood ratio test $p$-values from the univariable regression are given in Table S2 in the Supplementary Material.

Problem-focussed strategies

Active coping is used more by those with better bulbar function $(1.08(95 \% \mathrm{Cl}: 1.01,1.16))$. The use of Restraint was associated with both sex and functional ability in the respiratory domain. Females were $1.79(95 \% \mathrm{Cl}: 1.08,2.95)$ times as likely as males to use this strategy at higher levels and there was less usage of Restraint with increasing functional ability in the respiratory domain $(0.868(95 \% \mathrm{Cl}$ : $0.771,0.977))$. Similarly, Seeking of instrumental social support was used at higher levels by females compared to males $(1.83(95 \% \mathrm{Cl}: 1.13,2.97))$. The use of Planning and Suppression of competing activities were not found to be significantly associated with any of the covariates tested.

Emotion-focussed strategies

In the univariable analysis, Seeking of emotional social support was found to be associated with sex and disease duration. However, in the multiple regression marital status was found to be significantly associated with Seeking of emotional social support after sex was adjusted for, whereas 
disease duration was no longer a predictor. Females were $2.38(95 \% \mathrm{Cl}: 1.44,3.94)$ times as likely to report Seeking emotional social support at higher levels compared to males, and married individuals were $2.07(95 \% \mathrm{Cl}: 1.15,3.72)$ times as likely to utilise this strategy at higher levels compared to individuals without a spouse. The utilisation of Positive re-interpretation and growth and Denial were found to increase with greater functional ability in the motor domain $(1.06(95 \% \mathrm{Cl}: 1.01,1.1)$ and $1.07(95 \% \mathrm{Cl}: 1.02,1.12)$, respectively). Turning to religion was found to be utilised at higher levels with increasing age $(1.04(95 \% \mathrm{Cl}: 1.01,1.06))$. There was no evidence that the use of Acceptance is associated with any of the covariates tested here.

\section{Other strategies}

The utilisation of Focus on and venting of emotions was found to be associated with sex, age and functional ability in the bulbar domain. Venting was used less with increasing age and better bulbar function $(0.964(95 \% \mathrm{Cl}: 0.943,0.985)$ and $0.91(95 \% \mathrm{Cl}: 0.848,0.976)$, respectively). Females were $2.63(95 \% \mathrm{Cl}: 1.6,4.35)$ times as likely to use this strategy at higher levels compared to males. Behavioural and Mental disengagement were used more by females compared to males (2.05 (95\%Cl: 1.24, 3.37) and $2.62(95 \% \mathrm{Cl}: 1.58,4.33)$, respectively). Mental disengagement was used less with longer disease duration $(0.795(95 \% \mathrm{Cl}: 0.647,0.976))$. Substance use was found to be strongly associated with onset type; limb onset patients were $3.06(95 \% \mathrm{Cl}: 1.15,8.14)$ times as likely to use it at higher levels compared to bulbar onset patients. The number of individuals with respiratory onset disease was too low to be able to assess differences in usage compared to bulbar onset. There was no evidence that the utilisation of Humour is associated with any of the covariates tested here.

\section{Discussion}

This is by far the largest study undertaken to assess the strategies which patients use to cope with the physical and psychological challenges of MND. It demonstrates that people with MND draw on a 
very diverse repertoire of strategies, varying from those considered positive and beneficial, such as Acceptance, to those typically considered maladaptive, such as Substance abuse.

The original work on the COPE60 posited "acceptance to be particularly important in circumstances in which the stressor is something that must be accommodated to" ${ }^{15}$; the current inability to cure or slow MND makes it an exemplar of a stressor which must be accommodated to. In this study Acceptance is the most frequently used strategy, in keeping with results from a French population studied by Montel et al. ${ }^{14}$. Coping through acceptance has been shown to predict more positive adjustment to the diagnosis of cancer ${ }^{19}$, and to reduce anxiety and depression in multiple sclerosis $^{20}$. In chronic pain from muscular dystrophy, multiple sclerosis, post-polio syndrome, or spinal cord injury, pain acceptance related to less emotional distress ${ }^{21}$.

While there are many different patterns of use of the different coping strategies, our results show that use of different strategies is significantly associated with factors, which are readily evident in clinical care. These include demographic variables, like age, gender, and marital status, and disease characteristics, such as limb or bulbar onset. Understanding of this can help the clinical team intuit which coping strategies may be more readily accessed by the patient.

We found that females are more likely to Seek emotional social support and to Seek instrumental social support, i.e. assistance or information about what to do. Social support in MND has been associated with better quality of life ${ }^{22}$, so these significant gender differences in use of social support may imply gender differences in behaviours supporting quality of life. However, the reality may be more nuanced. In common with much previous research, the COPE60 addresses in-person social support, and may under-estimate seeking social support through new means such as social media or the internet, which have been shown to be more frequently used for support seeking by males $^{23}$. 
In this study females were more than twice as likely to report greater use of three strategies which may impede their ability to engage with problem solving; these are Behavioural and Mental disengagement, which refer respectively to withdrawing from efforts to achieve a difficult task or psychological disengagement from the task, and Focus on and venting of emotions, or concentrating upon and venting emotional distress. Greater use of behavioural disengagement has been associated with depression, although whether depression leads to disengagement or vice versa could not be determined ${ }^{24}$.

Restraint refers to coping through holding back attempts to act until their use appears opportune. We found that females use this strategy to a greater extent than males but whether this reflects selfcontrol or lack of confidence to act remains uncertain. Patients with worse respiratory function also use Restraint. Patients using Restraint may benefit from discussion and advice from professionals to help them decide whether they can act and when.

In keeping with previous research, both religion ${ }^{14} 25$ and venting of emotions ${ }^{9}$ were little used but our larger sample size allowed detection of clear age differences in use of these coping strategies; religion was used more with increasing age and venting of emotions less. We did not find other differences in strategy use by age, unlike earlier work with a smaller sample size $(n=49)$ which found that emotional support, venting, positive reframing, planning and humour were used more by patients aged under 55 years.

Use of particular coping strategies is constrained by the patient's ability to successfully employ a strategy, which may be influenced by their personal situation or disability. We found that the capacity for Seeking emotional social support is strengthened by having a partner; married people were over twice as likely to use this strategy at higher levels compared to people of the same sex who are not married. Patients with better motor function were more likely to use Positive reinterpretation and growth, where the situation is depicted in a positive light; and Denial, where the situation is not acknowledged; both strategies are more viable for patients with less impaired 
function and greater independence. For those who retain the ability to speak, it is easier to access the coping strategies of Active coping through negotiating problem-solving behaviours. While Substance Use was rarely cited as a coping strategy, if used it related to alcohol excess and was over 3 times more common in limb compared to bulbar onset patients.

The current cross-sectional results do not allow us to formally assess any causal links between disease characteristics and coping strategy utilisation. Neither can we determine whether use of coping strategies changes over time, but the influence of disability may be anticipated to alter with disease progression. Earlier work found that longer disease duration was correlated with acceptance, positive reframing and humour ${ }^{14}$, which the authors suggested might reflect patients adjusting to the condition. Our analysis shows that with longer disease duration patients are less able to mentally disengage as a means of coping, and they are more likely to turn to religion, though overall use of religion for coping remains infrequent.

Furthering the understanding of the use of coping strategies will help clinicians to understand which strategies patients may be more likely to utilise, based on their personal and disease characteristics. Consideration of these data remind clinicians that not all strategies are feasible for people with MND due to their personal situations or the disabilities arising from their disease. Conversely, patients with particular demographic or disease profiles are more likely to utilise strategies associated with worse outcomes and may need additional support. Targeted advice on coping may improve coping capacity and facilitate psychosocial adjustment.

\section{Acknowledgements}

We thank the participants and their families for their invaluable contributions; the research and clinical staff for recruitment, and the TONiC team.

\section{Funding details}


This work was supported by the MS Society, the MNDA, the NIHR CLRN, the Neurological Disability

Fund 4530, and unrestricted grants from Biogen, Genzyme, Merck, Novartis, Roche and Teva.

\section{Conflict of interest}

The authors report no conflicts of interest.

\section{References}

1. Wijesekera LC, Leigh PN. Amyotrophic lateral sclerosis. Orphanet J Rare Dis. 2009;4:3.

2. Musaro A. Understanding ALS: new therapeutic approaches. FEBS J. 2013;280(17):43154322.

3. Goldstein LH, Atkins L, Leigh PN. Correlates of Quality of Life in people with motor neuron disease (MND). Amyotroph Lateral Scler Other Motor Neuron Disord. 2002;3(3):123-129.

4. Chio A, Gauthier A, Montuschi A, et al. A cross sectional study on determinants of quality of life in ALS. J Neurol Neurosurg Psychiatry. 2004;75(11):1597-1601.

5. Matuz T, Birbaumer N, Hautzinger M, Kubler A. Coping with amyotrophic lateral sclerosis: an integrative view. J Neurol Neurosurg Psychiatry. 2010;81(8):893-898.

6. Matuz T, Birbaumer N, Hautzinger M, Kubler A. Psychosocial adjustment to ALS: a longitudinal study. Front Psychol. 2015;6:1197.

7. Gibbons C, Thornton E, Ealing J, et al. The impact of fatigue and psychosocial variables on quality of life for patients with motor neuron disease. Amyotroph Lateral Scler Frontotemporal Degener. 2013;14(7-8):537-545.

8. Folkman S, Lazarus RS. The relationship between coping and emotion: implications for theory and research. Soc Sci Med. 1988;26(3):309-317.

9. Jakobsson Larsson B, Nordin K, Askmark H, Nygren I. Coping strategies among patients with newly diagnosed amyotrophic lateral sclerosis. J Clin Nurs. 2014;23(21-22):3148-3155.

10. Tramonti F, Bongioanni P, Fanciullacci C, Rossi B. Balancing between autonomy and support: coping strategies by patients with amyotrophic lateral sclerosis. J Neurol Sci. 2012;320(12):106-109.

11. Hogg KE, Goldstein LH, Leigh PN. The psychological impact of motor neurone disease. Psychol Med. 1994;24(3):625-632.

12. Lee JN, Rigby SA, Burchardt F, Thornton EW, Dougan C, Young CA. Quality of life issues in motor neurone disease: the development and validation of a coping strategies questionnaire, the MND Coping Scale. J Neurol Sci. 2001;191(1-2):79-85.

13. Montel S, Albertini L, Desnuelle C, Spitz E. The impact of active coping strategies on survival in ALS: the first pilot study. Amyotroph Lateral Scler. 2012;13(6):599-601.

14. Montel S, Albertini L, Spitz E. Coping strategies as related to medical and demographic data in amyotrophic lateral sclerosis. Acta Neurol Scand. 2012;125(2):136-141.

15. Carver CS, Scheier MF, Weintraub JK. Assessing coping strategies: a theoretically based approach. J Pers Soc Psychol. 1989;56(2):267-283. 
16. Cedarbaum JM, Stambler N, Malta E, et al. The ALSFRS-R: a revised ALS functional rating scale that incorporates assessments of respiratory function. BDNF ALS Study Group (Phase III). J Neurol Sci. 1999;169(1-2):13-21.

17. Rasch G. Probabilistic models for some intelligence and achievement tests. Copenhagen: Danish Institute for Educational Research. 1960.

18. Yee TW. The VGAM Package for Categorical Data Analysis. J Stat Softw. 2010;32(10):1-34.

19. Stanton AL, Danoff-Burg S, Huggins ME. The first year after breast cancer diagnosis: hope and coping strategies as predictors of adjustment. Psychooncology. 2002;11(2):93-102.

20. Chalk HM. Mind over matter: cognitive - behavioral determinants of emotional distress in multiple sclerosis patients. Psychol Health Med. 2007;12(5):556-566.

21. Kratz AL, Hirsh AT, Ehde DM, Jensen MP. Acceptance of pain in neurological disorders: associations with functioning and psychosocial well-being. Rehabil Psychol. 2013;58(1):1-9.

22. Lule D, Pauli S, Altintas E, et al. Emotional adjustment in amyotrophic lateral sclerosis (ALS). J Neurol. 2012;259(2):334-341.

23. Rife SC, Kerns KA, Updegraff JA. Seeking support in response to social and achievement stressors: A multivenue analysis. Pers Relationship. 2016;23(2):364-379.

24. Orzechowska A, Zajaczkowska M, Talarowska M, Galecki P. Depression and ways of coping with stress: a preliminary study. Med Sci Monit. 2013;19:1050-1056.

25. Hogden A, Greenfield D, Nugus P, Kiernan MC. What influences patient decision-making in amyotrophic lateral sclerosis multidisciplinary care? A study of patient perspectives. Patient Prefer Adherence. 2012;6:829-838. 


\section{Figures}

Figure 1: Method for collapsing COPE60 outcome scores into groups for analysis

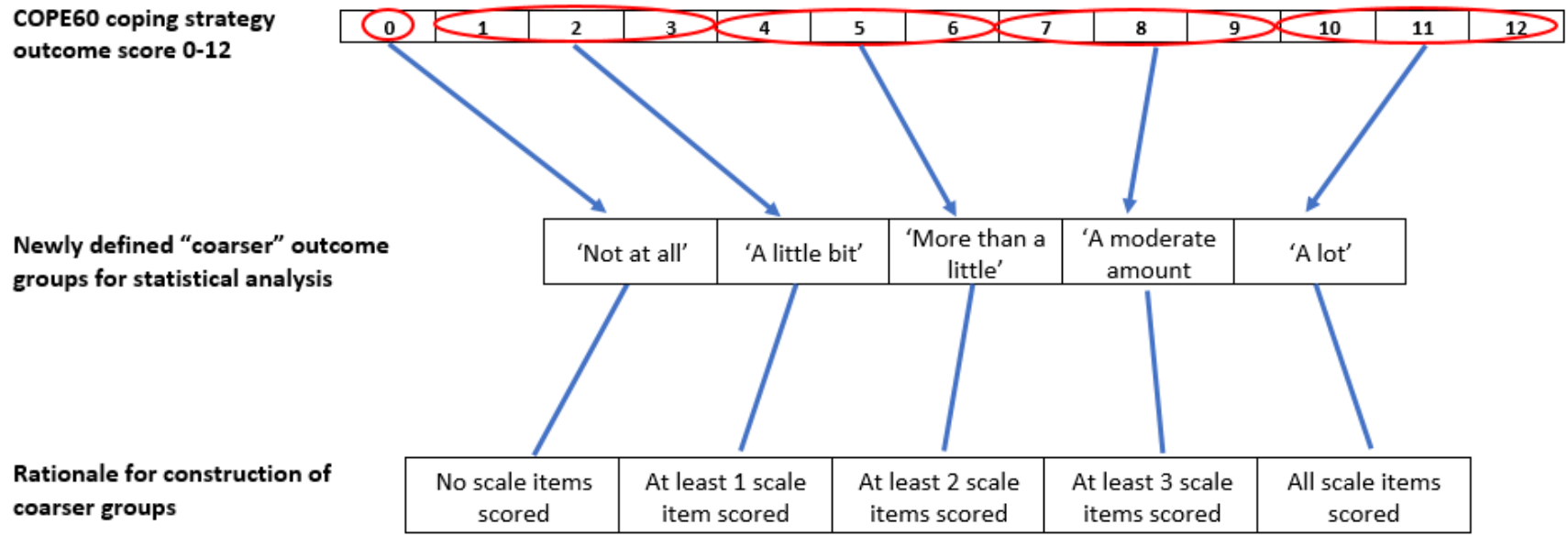


Tables

Table 1: Demographics of the study population

\begin{tabular}{|c|c|c|}
\hline & $\begin{array}{r}\text { Summary statistics in the } \\
\text { study population }\end{array}$ & $\begin{array}{r}\text { Number of individuals for whom } \\
\text { these data are missing }\end{array}$ \\
\hline $\mathrm{N}$ & 233 & \\
\hline age (mean (sd)) & 64.42 (11.09) & 0 \\
\hline $\operatorname{sex}=M(\%)$ & $148(63.5)$ & 0 \\
\hline status $=$ married $(\%)$ & $183(78.5)$ & 5 \\
\hline duration (median [IQR]) & $18.10[8.70,41.00]$ & 17 \\
\hline onset_type (\%) & & 16 \\
\hline Bulbar & $61(26.2)$ & \\
\hline Limb & $169(72.5)$ & \\
\hline Respiratory & $3(1.3)$ & \\
\hline ALSFRS-R bulbar (median [IQR]) & $8.16[5.89,12.00]$ & 1 \\
\hline ALSFRS-R motor (median [IQR]) & $13.19[9.85,16.66]$ & 1 \\
\hline ALSFRS-R respiratory (median [IQR]) & $11.09[9.55,12.00]$ & 5 \\
\hline
\end{tabular}




\begin{tabular}{|c|c|c|c|c|c|c|c|c|c|c|c|c|c|}
\hline & 0 & 1 & 2 & 3 & 4 & 5 & 6 & 7 & 8 & 9 & 10 & 11 & 12 \\
\hline Planning & & & & & & & $M$ & & & & & & \\
\hline Active coping & & & & & & & M & & & & & & \\
\hline Restraint & & & & & & & $M$ & & & & & & \\
\hline $\begin{array}{l}\text { Suppression of } \\
\text { competing activities }\end{array}$ & & & & & $M$ & & & & & & & & \\
\hline $\begin{array}{l}\text { Seeking of instru- } \\
\text { mental social support }\end{array}$ & $M$ & & & & & & & & & & & & \\
\hline $\begin{array}{l}\text { Seeking of emotional } \\
\text { social support }\end{array}$ & & & & & M & & & & & & & & \\
\hline $\begin{array}{l}\text { Positive reinterpret- } \\
\text { ation and growth }\end{array}$ & & & & & & & $\mathrm{M}$ & & & & & & \\
\hline Acceptance & & & & & & & & & & & & & $M$ \\
\hline Denial & M & & & & & & & & & & & & \\
\hline Turning to religion & M & & & & & & & & & & & & \\
\hline $\begin{array}{l}\text { Focus on and venting } \\
\text { of emotions }\end{array}$ & M & & & & & & & & & & & & \\
\hline $\begin{array}{l}\text { Mental } \\
\text { disengagement }\end{array}$ & & & & $M$ & & & & & & & & & \\
\hline $\begin{array}{l}\text { Behavioural } \\
\text { disengagement }\end{array}$ & $M$ & & & & & & & & & & & & \\
\hline Humour & $M$ & & & & & & & & & & & & \\
\hline Substance use & M & & & & & & & & & & & & \\
\hline
\end{tabular}

\begin{tabular}{|cl|}
\hline $\begin{array}{c}\text { Symbol/ } \\
\text { Shading }\end{array}$ & Indicates value of: \\
\hline & $\begin{array}{l}\text { Minimum to maximum } \\
\text { response } \\
\text { First to third quartile } \\
\\
\end{array}$ Median \\
& Mode \\
\hline
\end{tabular}


Table 3: Odds ratios and 95\% profile likelihood confidence intervals resulting from the univariable regression analyses. All figures are rounded to 3 significant digits and significant results are highlighted in red.

\begin{tabular}{|c|c|c|c|c|c|c|c|c|c|}
\hline & Sex=male & Age & $\begin{array}{l}\text { Marital } \\
\text { status=mar } \\
\text { ied }\end{array}$ & $\begin{array}{l}\text { Log(diseas } \\
\text { e } \\
\text { duration) }\end{array}$ & $\begin{array}{l}\text { Onset } \\
\text { type=Limb }\end{array}$ & $\begin{array}{l}\text { Onset } \\
\text { type=Respira } \\
\text { tory }\end{array}$ & $\begin{array}{l}\text { ALSFRS-R } \\
\text { bulbar }\end{array}$ & $\begin{array}{l}\text { ALSFRS-R } \\
\text { motor }\end{array}$ & $\begin{array}{l}\text { ALSFRS-R } \\
\text { respirato } \\
\text { ry }\end{array}$ \\
\hline planning & $\begin{array}{l}0.844 \\
(0.523,1.3 \\
6)\end{array}$ & $\begin{array}{l}0.985 \\
(0.964,1 . \\
01)\end{array}$ & $\begin{array}{l}0.856 \\
(0.488,1.5)\end{array}$ & $\begin{array}{l}0.998 \\
(0.819,1.2 \\
2)\end{array}$ & $\begin{array}{l}1.06 \\
(0.625,1.7 \\
9)\end{array}$ & $\begin{array}{l}9.77 \\
(0.809,118)\end{array}$ & $\begin{array}{l}1.07 \\
(0.999,1.1 \\
4)\end{array}$ & $\begin{array}{l}1.03 \\
(0.988,1 . \\
07)\end{array}$ & $\begin{array}{l}1.08 \\
(0.967,1 . \\
21)\end{array}$ \\
\hline $\begin{array}{l}\text { Active } \\
\text { coping }\end{array}$ & $\begin{array}{l}0.883 \\
(0.544,1.4 \\
3)\end{array}$ & $\begin{array}{l}0.99 \\
(0.969,1 . \\
01)\end{array}$ & $\begin{array}{l}1.01 \\
(0.57,1.78)\end{array}$ & $\begin{array}{l}1.06 \\
(0.869,1.3 \\
)\end{array}$ & $\begin{array}{l}1.17 \\
(0.689,2)\end{array}$ & $\begin{array}{l}2.15 \\
(0.257,17.9)\end{array}$ & $\begin{array}{l}1.08 \\
(1.01,1.16 \\
)\end{array}$ & $\begin{array}{l}1.02 \\
(0.979,1 . \\
06)\end{array}$ & $\begin{array}{l}1.06 \\
(0.944,1 . \\
19)\end{array}$ \\
\hline Restraint & $\begin{array}{l}0.595 \\
(0.362,0.9 \\
77)\end{array}$ & $\begin{array}{l}1.02 \\
(0.994,1 . \\
04)\end{array}$ & $\begin{array}{l}0.748 \\
(0.42,1.33)\end{array}$ & $\begin{array}{l}0.956 \\
(0.781,1.1 \\
7)\end{array}$ & $\begin{array}{l}1.24 \\
(0.722,2.1 \\
3)\end{array}$ & $\begin{array}{l}3.35 \\
(0.399,28.2)\end{array}$ & $\begin{array}{l}1.02 \\
(0.95,1.09 \\
)\end{array}$ & $\begin{array}{l}1.01 \\
(0.965,1 . \\
05)\end{array}$ & $\begin{array}{l}0.881 \\
(0.784,0 . \\
99)\end{array}$ \\
\hline $\begin{array}{l}\text { Suppression } \\
\text { of } \\
\text { competing } \\
\text { activities }\end{array}$ & $\begin{array}{l}0.686 \\
(0.419,1.1 \\
2)\end{array}$ & $\begin{array}{l}0.997 \\
(0.976,1 . \\
02)\end{array}$ & $\begin{array}{l}1.27 \\
(0.712,2.25 \\
)\end{array}$ & $\begin{array}{l}0.857 \\
(0.699,1.0 \\
5)\end{array}$ & $\begin{array}{l}1.01 \\
(0.589,1.7 \\
3)\end{array}$ & $\begin{array}{l}1.75 \\
(0.206,14.8)\end{array}$ & $\begin{array}{l}0.998 \\
(0.931,1.0 \\
7)\end{array}$ & $\begin{array}{l}1.04 \\
(0.995,1 . \\
08)\end{array}$ & $\begin{array}{l}0.966 \\
(0.861,1 . \\
09)\end{array}$ \\
\hline $\begin{array}{l}\text { Seeking of } \\
\text { instrumental } \\
\text { social } \\
\text { support }\end{array}$ & $\begin{array}{l}0.547 \\
(0.337,0.8 \\
89)\end{array}$ & $\begin{array}{l}0.992 \\
(0.972,1 . \\
01)\end{array}$ & $\begin{array}{l}1.13 \\
(0.642,1.98 \\
)\end{array}$ & $\begin{array}{l}1.05 \\
(0.862,1.2 \\
8)\end{array}$ & $\begin{array}{l}0.935 \\
(0.553,1.5 \\
8)\end{array}$ & $\begin{array}{l}1.09 \\
(0.136,8.73)\end{array}$ & $\begin{array}{l}1 \\
(0.939,1.0 \\
7)\end{array}$ & $\begin{array}{l}1.01 \\
(0.969,1 . \\
05)\end{array}$ & $\begin{array}{l}1.01 \\
(0.901,1 . \\
13)\end{array}$ \\
\hline $\begin{array}{l}\text { Seeking of } \\
\text { emotional } \\
\text { social } \\
\text { support }\end{array}$ & $\begin{array}{l}0.499 \\
(0.307,0.8 \\
1)\end{array}$ & $\begin{array}{l}0.987 \\
(0.967,1 . \\
01)\end{array}$ & $\begin{array}{l}1.58 \\
(0.899,2.78 \\
)\end{array}$ & $\begin{array}{l}0.817 \\
(0.669,0.9 \\
96)\end{array}$ & $\begin{array}{l}0.771 \\
(0.456,1.3 \\
)\end{array}$ & $\begin{array}{l}0.966 \\
(0.121,7.7)\end{array}$ & $\begin{array}{l}1 \\
(0.94,1.07 \\
)\end{array}$ & $\begin{array}{l}1.02 \\
(0.976,1 . \\
06)\end{array}$ & $\begin{array}{l}1.02 \\
(0.911,1 . \\
14)\end{array}$ \\
\hline $\begin{array}{l}\text { Positive } \\
\text { reinterpreta } \\
\text { tion and } \\
\text { growth }\end{array}$ & $\begin{array}{l}0.775 \\
(0.479,1.2 \\
5)\end{array}$ & $\begin{array}{l}0.982 \\
(0.962,1)\end{array}$ & $\begin{array}{l}0.761 \\
(0.433,1.34 \\
)\end{array}$ & $\begin{array}{l}1.01 \\
(0.831,1.2 \\
4)\end{array}$ & $\begin{array}{l}1.14 \\
(0.671,1.9 \\
\text { 3) }\end{array}$ & $\begin{array}{l}1.45 \\
(0.18,11.7)\end{array}$ & $\begin{array}{l}1.06 \\
(0.987,1.1 \\
\text { 3) }\end{array}$ & $\begin{array}{l}1.06 \\
(1.01,1.1 \\
)\end{array}$ & $\begin{array}{l}1.02 \\
(0.913,1 . \\
15)\end{array}$ \\
\hline Acceptance & $\begin{array}{l}0.841 \\
(0.517,1.3 \\
7)\end{array}$ & $\begin{array}{l}1 \\
(0.98,1.0 \\
2)\end{array}$ & $\begin{array}{l}0.666 \\
(0.374,1.19 \\
)\end{array}$ & $\begin{array}{l}0.93 \\
(0.761,1.1 \\
4)\end{array}$ & $\begin{array}{l}1.52 \\
(0.895,2.5 \\
9)\end{array}$ & $\begin{array}{l}5.57 \\
(0.466,66.6)\end{array}$ & $\begin{array}{l}1.04 \\
(0.973,1.1 \\
2)\end{array}$ & $\begin{array}{l}0.991 \\
(0.95,1.0 \\
3)\end{array}$ & $\begin{array}{l}1 \\
(0.893,1 . \\
12)\end{array}$ \\
\hline Denial & 0.729 & 1.01 & 0.96 & 0.866 & 0.817 & 0.643 & 1 & 1.07 & 0.997 \\
\hline
\end{tabular}




\begin{tabular}{|c|c|c|c|c|c|c|c|c|c|}
\hline & $\begin{array}{l}\text { (0.447,1.1 } \\
\text { 9) }\end{array}$ & $\begin{array}{l}0.987,1 . \\
03)\end{array}$ & $\begin{array}{l}(0.541,1.71 \\
)\end{array}$ & $\begin{array}{l}(0.706,1.0 \\
6)\end{array}$ & $\begin{array}{l}(0.478,1.4 \\
)\end{array}$ & $(0.0738,5.61)$ & $\begin{array}{l}\text { (0.934,1.0 } \\
\text { 7) }\end{array}$ & $\begin{array}{l}(1.02,1.1 \\
2)\end{array}$ & $\begin{array}{l}(0.888,1 . \\
12)\end{array}$ \\
\hline $\begin{array}{l}\text { Turning to } \\
\text { religion }\end{array}$ & $\begin{array}{l}0.628 \\
(0.369,1.0 \\
7)\end{array}$ & $\begin{array}{l}1.04 \\
(1.01,1.0 \\
6)\end{array}$ & $\begin{array}{l}0.792 \\
(0.427,1.47 \\
)\end{array}$ & $\begin{array}{l}1.22 \\
(0.971,1.5 \\
\text { 3) }\end{array}$ & $\begin{array}{l}0.94 \\
(0.521,1.7 \\
)\end{array}$ & $\begin{array}{l}3.31 \\
(0.411,26.6)\end{array}$ & $\begin{array}{l}1.01 \\
(0.938,1.0 \\
9)\end{array}$ & $\begin{array}{l}1.06 \\
(1.01,1.1 \\
1)\end{array}$ & $\begin{array}{l}1.03 \\
(0.908,1 . \\
18)\end{array}$ \\
\hline $\begin{array}{l}\text { Focus on } \\
\text { and venting } \\
\text { of emotions }\end{array}$ & $\begin{array}{l}0.36 \\
(0.219,0.5 \\
93)\end{array}$ & $\begin{array}{l}0.971 \\
(0.95,0.9 \\
92)\end{array}$ & $\begin{array}{l}1.12 \\
(0.637,1.98 \\
)\end{array}$ & $\begin{array}{l}0.922 \\
(0.756,1.1 \\
3)\end{array}$ & $\begin{array}{l}0.554 \\
(0.325,0.9 \\
43)\end{array}$ & $\begin{array}{l}0.339 \\
(0.0404,2.84)\end{array}$ & $\begin{array}{l}0.919 \\
(0.859,0.9 \\
84)\end{array}$ & $\begin{array}{l}1.01 \\
(0.971,1 . \\
06)\end{array}$ & $\begin{array}{l}1 \\
(0.892,1 . \\
12)\end{array}$ \\
\hline $\begin{array}{l}\text { Behavioural } \\
\text { disengagem } \\
\text { ent }\end{array}$ & $\begin{array}{l}0.489 \\
(0.297,0.8 \\
05)\end{array}$ & $\begin{array}{l}1.01 \\
(0.991,1 . \\
03)\end{array}$ & $\begin{array}{l}0.763 \\
(0.429,1.36 \\
)\end{array}$ & $\begin{array}{l}1.08 \\
(0.882,1.3 \\
2)\end{array}$ & $\begin{array}{l}0.832 \\
(0.486,1.4 \\
2)\end{array}$ & $\begin{array}{l}0.283 \\
(0.0321,2.5)\end{array}$ & $\begin{array}{l}0.942 \\
(0.879,1.0 \\
1)\end{array}$ & $\begin{array}{l}0.972 \\
(0.932,1 . \\
01)\end{array}$ & $\begin{array}{l}0.92 \\
(0.819,1 . \\
03)\end{array}$ \\
\hline $\begin{array}{l}\text { Mental } \\
\text { disengagem } \\
\text { ent }\end{array}$ & $\begin{array}{l}0.371 \\
(0.224,0.6 \\
14)\end{array}$ & $\begin{array}{l}0.981 \\
(0.96,1)\end{array}$ & $\begin{array}{l}0.802 \\
(0.453,1.42 \\
)\end{array}$ & $\begin{array}{l}0.779 \\
(0.635,0.9 \\
55)\end{array}$ & $\begin{array}{l}0.629 \\
(0.368,1.0 \\
8)\end{array}$ & $\begin{array}{l}0.48 \\
1(0.0569,4.0 \\
7)\end{array}$ & $\begin{array}{l}0.944 \\
(0.881,1.0 \\
1)\end{array}$ & $\begin{array}{l}1.02 \\
(0.975,1 . \\
06)\end{array}$ & $\begin{array}{l}0.963 \\
(0.858,1 . \\
08)\end{array}$ \\
\hline humour & $\begin{array}{l}1.07 \\
(0.666,1.7 \\
3)\end{array}$ & $\begin{array}{l}0.987 \\
(0.966,1 . \\
01)\end{array}$ & $\begin{array}{l}0.767 \\
(0.438,1.34 \\
)\end{array}$ & $\begin{array}{l}1.05 \\
(0.861,1.2 \\
8)\end{array}$ & $\begin{array}{l}1.29 \\
(0.764,2.1 \\
8)\end{array}$ & $\begin{array}{l}5.24 \\
(0.645,42.6)\end{array}$ & $\begin{array}{l}1.03 \\
(0.964,1.1 \\
)\end{array}$ & $\begin{array}{l}0.997 \\
(0.957,1 . \\
04)\end{array}$ & $\begin{array}{l}0.993 \\
(0.887,1 . \\
11)\end{array}$ \\
\hline $\begin{array}{l}\text { Substance } \\
\text { use }\end{array}$ & $\begin{array}{l}0.811 \\
(0.411,1.6 \\
)\end{array}$ & $\begin{array}{l}0.972 \\
(0.944,1)\end{array}$ & $\begin{array}{l}0.692 \\
(0.323,1.48 \\
)\end{array}$ & $\begin{array}{l}1.06 \\
(0.799,1.4 \\
2)\end{array}$ & $\begin{array}{l}3.06 \\
(1.15,8.14 \\
)\end{array}$ & $\begin{array}{l}1.48 \mathrm{e}-06 \\
(0, \operatorname{Inf})\end{array}$ & $\begin{array}{l}1.09 \\
(0.982,1.2 \\
1)\end{array}$ & $\begin{array}{l}0.977 \\
(0.921,1 . \\
04)\end{array}$ & $\begin{array}{l}0.953 \\
(0.815,1 . \\
11)\end{array}$ \\
\hline
\end{tabular}


Table 4: Odds ratios and $95 \%$ profile likelihood confidence intervals resulting from the multiple regression analyses. All figures are rounded to 3 significant digits.

\begin{tabular}{|c|c|c|c|c|c|c|c|c|c|}
\hline & Sex=male & Age & $\begin{array}{l}\text { Marital } \\
\text { status= } \\
\text { married }\end{array}$ & $\begin{array}{l}\text { Disease } \\
\text { duration }\end{array}$ & $\begin{array}{l}\text { Onset } \\
\text { type=Lim } \\
\text { b }\end{array}$ & $\begin{array}{l}\text { Onset } \\
\text { type=Resp } \\
\text { iratory }\end{array}$ & $\begin{array}{l}\text { ALSFRS-R } \\
\text { bulbar }\end{array}$ & $\begin{array}{l}\text { ALSFRS-R } \\
\text { motor }\end{array}$ & $\begin{array}{l}\text { ALSFRS-R } \\
\text { respiratory }\end{array}$ \\
\hline Planning & - & - & - & - & - & - & - & - & - \\
\hline $\begin{array}{l}\text { Active } \\
\text { coping }\end{array}$ & - & - & - & - & - & - & $\begin{array}{l}1.08(1.01, \\
1.16)\end{array}$ & - & - \\
\hline Restraint & $\begin{array}{l}0.559(0.33 \\
9,0.924)\end{array}$ & - & - & - & - & - & & - & $\begin{array}{l}0.868(0.77 \\
1,0.977)\end{array}$ \\
\hline $\begin{array}{l}\text { Suppressi } \\
\text { on of } \\
\text { competin } \\
\mathrm{g} \\
\text { activities }\end{array}$ & - & - & - & - & - & - & - & - & - \\
\hline $\begin{array}{l}\text { Seeking } \\
\text { instrume } \\
\text { ntal social } \\
\text { support }\end{array}$ & $\begin{array}{l}0.547(0.33 \\
7,0.889)\end{array}$ & - & - & - & - & - & & - & - \\
\hline $\begin{array}{l}\text { Seeking } \\
\text { emotional } \\
\text { social } \\
\text { support }\end{array}$ & $\begin{array}{l}0.42(0.254, \\
0.695)\end{array}$ & - & $\begin{array}{l}2.07(1.15 \\
, 3.72)\end{array}$ & - & - & - & - & - & - \\
\hline $\begin{array}{l}\text { Positive } \\
\text { reinterpre } \\
\text { tation } \\
\text { and } \\
\text { growth }\end{array}$ & - & - & - & - & - & - & - & $\begin{array}{l}1.06(1.01 \\
, 1.1)\end{array}$ & - \\
\hline $\begin{array}{l}\text { Acceptan } \\
\text { ce }\end{array}$ & - & - & - & - & - & - & & - & - \\
\hline Denial & - & - & - & - & - & - & - & $\begin{array}{l}1.07(1.02 \\
, 1.12)\end{array}$ & - \\
\hline $\begin{array}{l}\text { Turning } \\
\text { to religion }\end{array}$ & - & $\begin{array}{l}1.04(1.01,1 . \\
06)\end{array}$ & - & $\begin{array}{l}1.38(1.08,1 . \\
76)\end{array}$ & - & - & & $\begin{array}{l}1.08(1.03 \\
, 1.14)\end{array}$ & - \\
\hline
\end{tabular}




\begin{tabular}{|c|c|c|c|c|c|c|c|c|c|}
\hline $\begin{array}{l}\text { Focus on } \\
\text { and } \\
\text { venting of } \\
\text { emotions }\end{array}$ & $\begin{array}{l}0.38(0.23,0 . \\
627)\end{array}$ & $\begin{array}{l}0.964(0.94 \\
3,0.985)\end{array}$ & - & - & - & - & $\begin{array}{l}0.91(0.848 \\
, 0.976)\end{array}$ & - & - \\
\hline $\begin{array}{l}\text { Behaviour } \\
\text { al } \\
\text { disengage } \\
\text { ment }\end{array}$ & $\begin{array}{l}0.489(0.29 \\
7,0.805)\end{array}$ & - & - & - & - & - & & 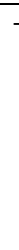 & - \\
\hline $\begin{array}{l}\text { Mental } \\
\text { disengaga } \\
\text { ment }\end{array}$ & $\begin{array}{l}0.381(0.23 \\
1,0.631)\end{array}$ & - & - & $\begin{array}{l}0.795(0.64 \\
7,0.976)\end{array}$ & - & - & - & 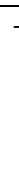 & - \\
\hline Humour & - & - & - & - & - & - & - & 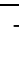 & - \\
\hline $\begin{array}{l}\text { Substanc } \\
\text { e use }\end{array}$ & - & - & - & - & $\begin{array}{l}3.06(1.15 \\
, 8.14)\end{array}$ & $\begin{array}{l}1.48 \mathrm{e}- \\
06(0, \operatorname{lnf})\end{array}$ & - & 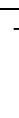 & - \\
\hline
\end{tabular}


Use of coping strategies in MND/ALS: association with demographic and disease-related characteristics

Supplementary Material

Schlüter DK, Holland D, Mills RJ, Young CA on behalf of the TONiC study group

Table S1: COPE-60 Inventory scales and concept definitions

Scale

Active coping

Planning

Suppression of competing activities

Restraint

Use of instrumental social support

Use of emotional social support

Positive reinterpretation and growth

Acceptance

Turning to religion

Focus on and venting of emotions

Denial

Behavioural disengagement

Mental disengagement

Substance use

Humour

\section{Activities undertaken by individual}

Taking steps to try to remove or circumvent the stressor or to ameliorate its effect

Thinking about how to cope with a stressor

Putting other tasks aside in order to deal with the stressor

Waiting until an appropriate opportunity to act presents itself

Seeking assistance or information

Seeking sympathy or understanding

Reframing the stressor in positive terms

Accepting the reality of a stressful situation

Using faith for support

The tendency to focus on whatever distress

or upset one is experiencing and to ventilate those feelings

Denying the reality of the stressor

Reducing one's effort to deal with the stressor

Using alternative activities to take one's mind off a problem

Using alcohol or drugs to reduce distress

Making jokes about the stressor

Derived from $^{12}$ 
Table S2: P-values from the likelihood ratio test comparing models with one covariate to models without explanatory variables. Values are rounded to three significant digits and values $<0.05$ are highlighted in red.

\begin{tabular}{|c|c|c|c|c|c|c|c|c|}
\hline & Sex & Age & $\begin{array}{l}\text { Marital } \\
\text { status }\end{array}$ & $\begin{array}{l}\text { Disease } \\
\text { duration }\end{array}$ & $\begin{array}{l}\text { Onset } \\
\text { type }\end{array}$ & $\begin{array}{l}\text { ALSFRS- } \\
\text { R } \\
\text { Bulbar }\end{array}$ & $\begin{array}{l}\text { ALSFRS- } \\
\text { R } \\
\text { Motor }\end{array}$ & $\begin{array}{l}\text { ALSFRS-R } \\
\text { Respiratory }\end{array}$ \\
\hline Planning & 0.488 & 0.14 & 0.574 & 0.982 & 0.116 & 0.0552 & 0.181 & 0.172 \\
\hline Active coping & 0.611 & 0.334 & 0.983 & 0.547 & 0.691 & 0.0244 & 0.353 & 0.338 \\
\hline Restraint & 0.0379 & 0.158 & 0.319 & 0.666 & 0.405 & 0.609 & 0.775 & 0.0329 \\
\hline $\begin{array}{l}\text { Suppression of } \\
\text { competing } \\
\text { activities }\end{array}$ & 0.132 & 0.765 & 0.419 & 0.139 & 0.85 & 0.949 & 0.0881 & 0.569 \\
\hline $\begin{array}{l}\text { Seeking } \\
\text { instrumental } \\
\text { social support }\end{array}$ & 0.0142 & 0.443 & 0.67 & 0.621 & 0.96 & 0.895 & 0.634 & 0.875 \\
\hline $\begin{array}{l}\text { Seeking } \\
\text { emotional } \\
\text { social support }\end{array}$ & 0.00487 & 0.222 & 0.106 & 0.045 & 0.62 & 0.89 & 0.426 & 0.73 \\
\hline $\begin{array}{l}\text { Positive } \\
\text { reinterpretation } \\
\text { and growth }\end{array}$ & 0.293 & 0.0882 & 0.344 & 0.897 & 0.848 & 0.115 & 0.0092 & 0.686 \\
\hline Acceptance & 0.483 & 0.915 & 0.149 & 0.478 & 0.13 & 0.242 & 0.659 & 0.979 \\
\hline
\end{tabular}




\begin{tabular}{|c|c|c|c|c|c|c|c|c|}
\hline Denial & 0.213 & 0.454 & 0.889 & 0.166 & 0.737 & 0.982 & 0.00183 & 0.967 \\
\hline $\begin{array}{l}\text { Turning to } \\
\text { religion }\end{array}$ & 0.0882 & 0.00594 & 0.464 & 0.0868 & 0.475 & 0.76 & 0.0176 & 0.608 \\
\hline $\begin{array}{l}\text { Focus on and } \\
\text { venting of } \\
\text { emotions }\end{array}$ & $\begin{array}{l}4.75 \mathrm{e}- \\
05\end{array}$ & 0.00677 & 0.693 & 0.441 & 0.068 & 0.0147 & 0.555 & 0.994 \\
\hline $\begin{array}{l}\text { Behavioural } \\
\text { disengagement }\end{array}$ & 0.00493 & 0.253 & 0.348 & 0.447 & 0.425 & 0.0957 & 0.191 & 0.157 \\
\hline $\begin{array}{l}\text { Mental } \\
\text { disengagement }\end{array}$ & $\begin{array}{l}9.12 \mathrm{e}- \\
05\end{array}$ & 0.0857 & 0.455 & 0.0149 & 0.218 & 0.0975 & 0.434 & 0.517 \\
\hline Humour & 0.77 & 0.209 & 0.359 & 0.625 & 0.269 & 0.379 & 0.903 & 0.9 \\
\hline Substance use & 0.547 & 0.053 & 0.356 & 0.667 & 0.0255 & 0.0943 & 0.434 & 0.561 \\
\hline
\end{tabular}

\section{References}

1. Carver CS, Scheier MF, Weintraub JK. Assessing coping strategies: a theoretically based approach. J Pers Soc Psychol. 1989;56(2):267-283.

2. Litman JA. The COPE inventory: Dimensionality and relationships with approach- and avoidance-motives and positive and negative traits. Personality and Individual Differences 2006;41:273-284. 